\title{
Policing Marginality in Public Space
}

\author{
JAMELIA N. MORGAN*
}

TABLE OF CONTENTS

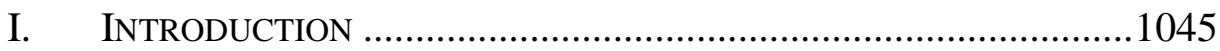

II. Policing Marginality in Public Space In Historical

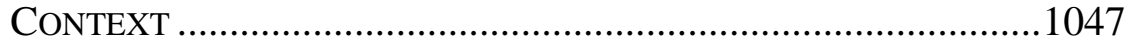

III. Constitutional Protections Against Policing

MARGINALITY: A FoCUS ON STATUS OFFENSES .........................1055

IV. CRIMINAl LAW's Public ORDERING FunCTION \& THE

Policing of Marginality In Public SpaCE ...........................1060

\section{INTRODUCTION}

The pandemic spurred by COVID-19 has illuminated in stark detail the threats to safety and health that have long-characterized the lived experiences of unsheltered individuals. ${ }^{1}$ The pandemic has brought to the forefront deeply rooted structural problems, which contributed to the social conditions now currently rendering houseless people particularly vulnerable to the brutal disease and premature death. ${ }^{2}$ Skyrocketing housing prices coupled with city-wide housing shortages have converged in recent years to create a nation-wide affordable housing crisis. ${ }^{3}$ According to a 2018 report by the National Low Income Housing Coalition, to meet existing housing demand, about 7.2 million

* Associate Professor of Law, University of Connecticut School of Law. For helpful comments and insights on earlier drafts of this Essay, special thanks to Amna Akbar, Chaz Arnett, Monica Bell, Alexandra Natapoff, and Jocelyn Simonson. I am grateful to Justin Hyland for exceptional research assistance, and to the editors of the Ohio State Law Journal for their careful review and thoughtful feedback.

${ }^{1}$ See Homelessness and Health: What's the Connection?, FACT SHEET (Nat'l Health Care for the Homeless Council), Feb. 2019, at 1, https://nhchc.org/wp-content/uploads/ 2019/08/homelessness-and-health.pdf [https://perma.cc/8AWJ-GKF7] ("People who are homeless have higher rates of illness and die on average 12 years sooner than the general U.S. population."); see also Seiji Hayashi, How Health and Homelessness Are ConnectedMedically, ATLANTIC (Jan. 25, 2016), https://www.theatlantic.com/politics/archive/2016/01/ how-health-and-homelessness-are-connectedmedically/458871/ [https://perma.cc/59A5JQLE] ("In a study published in the Journal of the American Public Health Association, Monica Bharel and her colleagues found that homeless individuals used the emergency room almost four times more than other low-income residents of Boston.").

${ }^{2}$ See People Experiencing Homelessness, CENTERS FOR DISEASE CONTROL \& PREVENTION, https://www.cdc.gov/coronavirus/2019-ncov/need-extra-precautions/home lessness.html [https://perma.cc/78BR-JT2E] (last updated Aug. 10, 2020).

${ }^{3}$ See generally NAT'L LOW InCOME Hous. CoAl., The GaP: A ShORTAge of AFFORDABLE HOMES (Mar. 2018), https://nlihc.org/sites/default/files/gap/Gap-Report_ 2018.pdf [https://perma.cc/7NJL-LJP4] (discussing the shortage of affordable and available rental homes throughout the nation and, more specifically, in the largest fifty metropolitan areas). 
more affordable rental housing units would have to be built across the United States. ${ }^{4}$ Although the severity of the problem varies across jurisdictions, the same report indicates that "[n]o state, including the District of Columbia, has an adequate supply of rental housing for extremely low income households." ${ }^{5} \mathrm{In}$ Los Angeles, perhaps the "epicenter" of the affordable housing crisis, ${ }^{6}$ the number of unsheltered people has increased $12 \%$ in Los Angeles County and $16 \%$ in the city of Los Angeles - a 52\% increase for the city since 2011.7 Approximately $75 \%$ of homeless people in Los Angeles are unsheltered and live outside. $^{8}$

The housing crisis seems to have also prompted local jurisdictions to ramp up quality-of-life policing efforts in public spaces. ${ }^{9}$ In this Essay, I suggest that the housing crisis in particular provides a case study from which to scrutinize some of the historical and ongoing harms that flow from managing access to public space using criminal laws - and why constitutional prohibitions against status crimes, one tool in the arsenal of challenges against quality-of-life policing, fail to protect against overcriminalization. The first part of the Essay provides a brief discussion of some of the past and present uses of criminal law enforcement to regulate the boundaries of, and behaviors within, public spaces with a focus on how those laws served to reinforce racial, gender, class and other status hierarchies. In particular, I discuss how the use of criminal laws to regulate access to, and behaviors in, public spaces reinforces both existing status hierarchies and contributes to ongoing criminalization of historically and currently marginalized groups. In the second half of the Essay, I discuss the recent Ninth Circuit case, Boise v. Martin, as an entry point into a discussion on the constitutional limits of criminalizing acts that occur in public because, in the words of Justice White in his concurrence in Powell v. Texas, the person accused

\section{${ }^{4} I d$. at 2 . \\ ${ }^{5} \mathrm{Id}$. at 8 .}

${ }^{6}$ Evan Symon, The Housing Crisis Part II: Los Angeles, CAL. Globe (Sept. 23, 2019), https://californiaglobe.com/section-2/the-housing-crisis-part-ii-los-angeles-how-thehousing-crisis-is-adding-to-the-homeless-crisis/ [https://perma.cc/G2E6-REUD].

${ }^{7}$ Benjamin Oreskes \& Doug Smith, Homelessness Jumps $12 \%$ in L.A. County and 16\% in the City; Officials 'Stunned', L.A. TIMES (June 4, 2019), https://www.latimes.com/ local/lanow/la-me-ln-homeless-count-encampment-affordable-housing-2019-results20190604-story.html [https://perma.cc/T8V9-EBKZ]; Reihan Salam, Los Angeles Is in Crisis. So Why Isn't It Building More Housing?, ATLANTIC (June 19, 2019), https://www.the atlantic.com/ideas/archive/2019/06/how-solve-los-angeless-homelessness-crisis/591976/ [https://perma.cc/C3JE-6PC5].

8 Jacob Siegel, Managed Obsolescence: Homelessness in America's Gilded Cities, AM. AFF. (Feb. 20, 2019), https://americanaffairsjournal.org/2019/02/managed-obsoles cence-homelessness-in-americas-gilded-cities/ [https://perma.cc/HXR4-4TA6].

${ }^{9}$ See Sarah Gillespie, Katrina Ballard, Samantha Batko, \& Emily Peiffer, Addressing Chronic Homelessness Through Policing Isn't Working. Housing First Strategies Are a Better Way, URB. INST.: URB. WIRE (June 29, 2020), https://www.urban.org/urban-wire/ addressing-chronic-homelessness-through-policing-isnt-working-housing-first-strategiesare-better-way [https://perma.cc/PF7G-W55Q]. 
has "no place else to go."10 I suggest that constitutional protections against the criminalization of status do little to limit or constrain an oft-ignored but harmful purpose of criminal law as applied to the policing of public space: the public ordering function. The public ordering function of criminal law highlights its role in targeting not only houseless individuals, but an array of marginalized groups deemed "out of place," disruptive, disorderly, or dangerous. ${ }^{11}$ Centering in on this function of criminal law permits a more practical view of the limits of existing constitutional protections and provides a framework to better account for the full scope of the harms stemming from ongoing quality-of-life policing efforts targeted at houseless individuals and other marginalized groups.

\section{Policing Marginality In Public Space IN HISTORICAL CONTEXT}

Quality-of-life offenses - nuisance laws, anti-loitering ordinances, criminal trespass laws, turnstile jumping ordinances, incommoding statutes, etc.- - work to confine, segregate, and impede the movement of otherized, and oft-racialized bodies in public places. Police possess wide discretion to cite and arrest for quality-of-life offenses ${ }^{12}$ and even though prosecution or conviction may not follow citations or arrest, enforcement serves social control or managerial purposes. ${ }^{13}$ Beyond the role of criminal legal system actors, private citizens wield considerable discretion in deciding what behaviors to alert law enforcement to, such as determinations as to which behaviors allegedly constitute disorderly conduct, which actions constitute alleged trespassing, and which individuals are otherwise deemed out of place. ${ }^{14}$ Vague and broad offenses, like disorderly conduct, can facilitate nefarious forms of "community participation." 15 Indeed, private citizens possess wholly unbridled discretion to

10 Powell v. Texas, 392 U.S. 514, 551 (1968) (White, J., concurring).

${ }^{11}$ See Alice Ristroph, Criminal Law as Public Ordering, 70(Supplement 1) U. TORONTO L.J. 64, 76-77 (2020) (noting that criminal laws criminalize "ordinary nonconformity").

${ }^{12}$ See, e.g., Debra Livingston, Police Discretion and the Quality of Life in Public Places: Courts, Communities, and the New Policing, 97 COLUM. L. REV. 551, 589 (1997).

${ }^{13} \mathrm{See}$, e.g., ISSA KoHLER-HAUSMANN, MisDEMEANORLAND: CRIMINAL COURTS AND Social Control in An Age of Broken Windows Policing 5-11 (2018); AleXANdra Natapoff, Punishment Without CRime: How Our Massive Misdemeanor System Traps the InNOCENT AND MAKes AMERICA More UneQual 7-9 (2018); Issa KohlerHausmann, Managerial Justice and Mass Misdemeanors, 66 STAN. L. REV. 611, 619-29 (2014).

${ }^{14}$ See, e.g., Antonia Noori Farzan, BBQ Becky, Permit Patty and Cornerstore Caroline: Too 'Cutesy' for Those White Women Calling Police on Black People?, WASH. Post (Oct. 19, 2018), https://www.washingtonpost.com/news/morning-mix/wp/2018/10/19/bbq-becky -permit-patty-and-cornerstore-caroline-too-cutesy-for-those-white-women-calling-cops-onblacks/?utm_term=.867b6dfde2c5 [https://perma.cc/A34B-4H52].

${ }^{15} \mathrm{Id}$. (describing white women who call police on Black people for "trivial or nonexistent offenses"). 
call on law enforcement based on what they deem to be unlawful conduct. ${ }^{16}$ For example, disorderly conduct ordinances provide mechanisms for communities to both determine which persons and which behaviors are deemed disorderly and then deputize law enforcement to facilitate removal of certain people from these public places. ${ }^{17}$ The regulating of racialized and historically marginalized people in certain spaces (e.g., gentrifying areas, white, affluent communities, etc.) has captured media attention through viral video accounts on social media. ${ }^{18}$

Quality-of-life offenses disproportionately target unsheltered communities. ${ }^{19}$ Though recent media accounts have focused on the rise of what some have termed a "war on homelessness," aggressive actions against the homeless are not new. ${ }^{20}$ Neither are restrictions on access to public space and the regulation of behavior in those public spaces for people, homeless or not, who occupy a position of precarity and marginality. ${ }^{21}$ For centuries, communities have used criminal laws to exclude negatively racialized and historically marginalized groups from accessing, using, or occupying public places. $^{22}$

Vagrancy, criminal trespass, and loitering laws were readily deployed to regulate access to, or behaviors in, public spaces among a wide swath of historically marginalized groups. Well into the twentieth century, vagrancy laws targeted a host of groups deemed undesirable, according to norms set by white

\footnotetext{
${ }^{16}$ See id. (recalling an incident in which a white woman called the police on a Black father yelling instructions to his son during a youth soccer game).

17 See Ristroph, supra note 11, at 75 (noting that "catch-all" statutory definitions of disorderly conduct are "slippery" and allow for law officers "to determine on the spot what counts as disorder").

${ }^{18}$ See, e.g., Ginia Bellafante, Why Amy Cooper's Use of 'African-American' Stung, N.Y. TiMES (May 29, 2020), https://www.nytimes.com/2020/05/29/nyregion/Amy-CooperCentral-Park-racism.html [https://perma.cc/VCD3-TTPT]; Elle Hunt, What Does it Mean to Be a 'Karen'? Karens Explain, GUARDIAN (May 13, 2020), https://www.theguardian.com/ lifeandstyle/2020/may/13/karen-meme-what-does-it-mean [https://perma.cc/LQ6H-C9XT].

${ }^{19}$ Law Enforcement Violence Against Women of Color \& Trans People of Color: A Critical Intersection of Gender Violence and State Violence, INCITE! WOMEN OF COLOR AGAINST VIOLENCE 18-19 (Aug. 1, 2018), https://incite-national.org/wp-content/uploads/ 2018/08/TOOLKIT-FINAL.pdf [https://perma.cc/8L8H-ZT87].

${ }^{20}$ See Ginia Bellafante, Are We Fighting a War on Homelessness? Or a War on the Homeless?, N.Y. TIMES (May 31, 2019), https://www.nytimes.com/2019/05/31/nyregion/ homelessness-shelters.html [https://perma.cc/W7K4RK6H].

${ }^{21}$ Kurt Iveson, We Don't Know What We've Got Till It's Gone - We Must Reclaim Public Space Lost to the Coronavirus Crisis, CONVERSATION (Apr. 15, 2020), https://www.theconversation.com/we-dont-know-what-weve-got-till-its-gone-we-mustreclaim-public-space-lost-to-the-coronavirus-crisis-135817 [https://perma.cc/JXL9-M6M8].

22 See generally ANTHONY BRUNDAGE, THE ENGLISH POOR LAws, 1700-1930 (2002) (discussing social class and the history of vagrancy laws); WILLIAM J. NOVAK, THE PEOPLE'S Welfare: LAW AND REgUlation IN NineteENTH-CENTURY AMERICA (1996) (discussing gender and the prosecution of "bawdy houses").
} 
dominant culture, by criminalizing a wide array of conduct including but not limited to:

Rogues and vagabonds, or dissolute persons who go about begging, common gamblers, persons who use juggling or unlawful games or plays, common drunkards, common night walkers, thieves, pilferers or pickpockets, traders in stolen property, lewd, wanton and lascivious persons, keepers of gambling places, common railers and brawlers, persons wandering or strolling around from place to place without any lawful purpose or object, habitual loafers, disorderly persons, persons neglecting all lawful business and habitually spending their time by frequenting houses of ill fame, gaming houses, or places where alcoholic beverages are sold or served, persons able to work but habitually living upon the earnings of their wives or minor children shall be deemed vagrants .... ${ }^{23}$

Indeed, throughout the nineteenth century, a number of vaguely-worded laws criminalizing breach of peace, disorderly houses, and begging in public by people with physical disabilities or deformities, were deployed to target a wide range of conduct that rendered certain groups vulnerable to criminalization. Those groups targeted by such enforcement regimes included individuals labeled as "undesirables" - including racial minorities, single women deemed promiscuous, and people with disabilities. ${ }^{24}$ These laws equipped local jurisdictions with a ready mechanism for policing access to public spaceswhether streets, parks, or walkways. ${ }^{25}$ For example, criminal trespass laws in particular targeted people deemed "out of place" in public spaces, and specifically targeted Black communities. ${ }^{26}$ In the words of Taja-Nia Y. Henderson and Jamila Jefferson-Jones, criminal trespass laws effectively constructed "Blackness as Trespass." 27 These laws have historically targeted Black communities in order to police spatial boundaries. ${ }^{28}$ As critical race

${ }^{23}$ Papachristou v. City of Jacksonville, 405 U.S. 156, 156 n.1 (1972) (quoting Jacksonville Ordinance Code $§ 26-57$ (1965)). In this celebrated opinion, Justice William O. Douglas declared the Jacksonville ordinance void for vagueness. Id. at 162. See generally Risa Goluboff, Vagrant Nation: Police Power, Constitutional Change, and the MAKING OF THE 1960S (2016) (describing the history of legal advocacy to dismantle the vagrancy regime).

${ }^{24}$ See supra notes 22-23 and accompanying text. See generally Nina Renata Aron, In the 1800s, There Were Literally Laws Against Being Ugly (and No Surprise Who Suffered Most), TiMELINE (July 13, 2017), https://timeline.com/in-the-1800s-there-were-literallylaws-against-being-ugly-and-no-surprise-who-suffered-most-c0b7a26ba8c9 [https://per ma.cc/XSD2-DF7F] (describing the rise of the "ugly law" and those disproportionately affected).

25 See Aron, supra note 24.

${ }^{26}$ See, e.g., Taja-Nia Y. Henderson \& Jamila Jefferson-Jones, \#LivingWhileBlack: Blackness as Nuisance, 69 AM. U. L. REV. 863, 870, 905-07 (2020) (detailing an incident where the intervention of law enforcement was used to preserve a spatial boundary).

${ }^{27}$ Id. at 879 .

${ }^{28}$ Id. at $879-80$. 
scholars have noted, Black communities were, and continue to be, routinely subjected to overpolicing and regulation in white communities ${ }^{29}$ and places that can be described as - to use the term coined by renowned sociologist Elijah Anderson - "the white space." 30 These criminal legacies continue to this day. ${ }^{31}$

Nineteenth century criminal laws and local ordinances that explicitly regulated gender and sexuality also served to manage access to, and behaviors in, public spaces. ${ }^{32}$ Municipalities targeted bawdy houses, dubbed houses of prostitution, aggressively enforcing public welfare offenses with the express goal of policing female "virtue" by closely regulating sexual expression. ${ }^{33}$ Similar efforts at regulating sexual expression in public targeted LGBTQ communities. Beginning in the mid-nineteenth century, laws criminalizing cross-dressing proliferated across the United States. ${ }^{34}$ According to William Eskridge, "By the beginning of the twentieth century, gender inappropriateness ... was increasingly considered a sickness and a public offense." 35 Indeed, well into the 1960s, lesbian, gay, and transgender communities were similarly targeted through lewd stings and so-called masquerade laws as police ramped up raids and arrests. ${ }^{36}$ This violence and mistreatment against LGBTQ communities during those raids, according to some commentators, in part served as a catalyst for the Stonewall Uprising in 1969.37

Even earlier, order maintenance policing served to prevent indigenous communities from accessing and enjoying public space in and around the area that would become the city of Los Angeles. Professor Kelly Lytle Hernández explains how white settlers deployed criminal law in early Los Angeles as part

${ }^{29}$ Priscilla A. Ocen, The New Racially Restrictive Covenant: Race, Welfare, and the Policing of Black Women in Subsidized Housing, 59 UCLA L. REV. 1540, 1550 (2012).

${ }^{30}$ Elijah Anderson, “The White Space,” 1 Soc. RACE \& ETHNICITY 10, 10 (2015); see also Angela Onwuachi-Willig, Policing the Boundaries of Whiteness: The Tragedy of Being "Out of Place" from Emmett Till to Trayvon Martin, 102 IowA L. REV. 1113, 1119 (2017); Addie C. Rolnick, Defending White Space, 40 CARDOZO L. REV. 1639, 1691, 1702 (2019).

${ }^{31}$ See P.R. Lockhart, Living While Black and the Criminalization of Blackness: White People Calling 911 on Black People for Things Like Napping and Sitting in Starbucks Points to a Deeper Problem, Vox (Aug. 1, 2018), https://www.vox.com/explainers/2018/8/1/ 17616528/racial-profiling-police-911-living-while-black (on file with the Ohio State Law Journal); see also supra note 18 and accompanying text.

32 See NovaK, supra note 22, at 166-68.

33 Id. at $162-71$.

${ }^{34}$ Hugh Ryan, How Dressing in Drag Was Labeled a Crime in the 20th Century, HISTORY (June 25, 2019), https://www.history.com/news/stonewall-riots-lgbtq-drag-threearticle-rule [https://perma.cc/D48E-5UZB].

35 William N. Eskridge, JR., GayLaW: Challenging the APARTHEID OF THE CloseT 28 (1999).

36 See Jordan Blair Woods, Don't Tap, Don't Stare, and Keep Your Hands to Yourself! Critiquing the Legality of Gay Sting Operations, 12 J. GENDER RACE \& JUST. 545, 552-53 (2009); Ryan, supra note 34.

${ }^{37}$ See Ryan, supra note 34. 
of a strategic campaign to dispossess Indigenous people of their lands largely based on pretextual justifications like public intoxication:

[T] he Californios of Los Angeles had concerns about the growing number of Indigenous peoples living in and around Los Angeles. Too many indios, they complained, spent their days playing peon (gambling) at the village or drinking in grog shops near the plaza.... In January 1836, the ayuntamiento [city council] required all Californios to sweep across the town every Sunday night to arrest "all drunken Indians." The [mayor] required all those arrested to pay a fine or be subject to forced labor on public works projects. ${ }^{38}$

In Los Angeles, as Professor Lytle Hernández illuminates, the policing of what white settlers labeled as disorder in public space served to reinforce racist norms that linked Indigenous communities to criminality, immorality, drunkenness, and laziness. Criminality in turn justified their imprisonment and, subsequently, the forced extraction of their labor through state-sanctioned convict leasing. ${ }^{39}$

In more contemporary times, order-maintenance policing has continued to serve to reinforce racist norms. ${ }^{40}$ For example, in a discussion of anti-loitering laws, Professor Dorothy Roberts has argued that "the identity of 'visibly lawless' people at the heart of vague loitering laws incorporates racist notions of criminality and legitimates police harassment of Black citizens." 41 Roberts goes on to explain that " $[\mathrm{t}]$ hese categories, however, are not created by policing strategies alone. [And while these] aggressive policing techniques impose norms on the community, they also reinforce pre-existing notions of criminality, disorder, and lawlessness." 42

Similar racialized conceptions of disorder may inform policing of young people of color, particularly, low-income Black and Latinx youth, resulting in hyper-surveillance and regulation of these young people in public spaces. ${ }^{43}$ For

38 Kelly LyTLE HERNÁNDEZ, CITY OF INMATES: CONQUEST, REBELLION, AND THE RISE OF HUMAN CAGING IN LOS ANGELES, 1771-1965, at 33 (2017).

${ }^{39} I d$. (noting "all unemployed Natives were to be arrested and sentenced to labor either on public projects of for private employers").

${ }^{40}$ See Jennifer M. Chacón and Susan Bibler Coutin, Racialization through Enforcement, in RACE, CRIMINAL Justice, AND Migration CONTROL: EnForCing THE Boundaries of Belonging 159, 172 (Mary Bosworth, Alpa Parmar \& Yolanda Vázquez eds., 2018) ("[P]rofiling practices 'bind and reif[y] the concepts of race and criminality, fixing them into the subconscious of the profiled, the profiler, and society at large."') (quoting Trevor G. Gardner, Racial Profiling as Collective Definition, 2 Soc. INCLUSION 52, 52 (2014)); Ristroph, supra note 11, at 78.

${ }^{41}$ Dorothy E. Roberts, Foreword, Race, Vagueness, and the Social Meaning of OrderMaintenance Policing, 89 J. CRIM. L. \& CRIMINOLOGY 775, 790 (1999).

$42 \mathrm{Id}$. at 804.

43 See, e.g., Megan Guza, Pittsburgh Police Chief Outlines Efforts to Curb Violence Downtown, TRIB LIVE (Sept. 30, 2016), https://archive.triblive.com/news/pittsburgh-policechief-outlines-efforts-to-curb-violence-downtown/ [https://perma.cc/TH7T-WKGA]; Madina Touré, Report: Black, Latino Youths Still Getting Arrested at Disproportionate Rates in NYC, POLITICO (July 13, 2020), https://www.politico.com/states/new-york/albany/ 
example, in Pittsburgh, Pennsylvania, after a string of fights among youth, police officers cordoned off sections of the downtown center to prevent all youth from gathering in spaces close to commercial centers, office buildings, bus terminals, and plazas. ${ }^{44}$ Such tactics, although purportedly aimed at curbing incidents involving fighting led to an effective ban targeting Black and Latinx youth and preventing them from accessing, using, or enjoying public space. ${ }^{45}$ Critics of gang injunctions have raised similar concerns about such broad spatial exclusions. ${ }^{46}$ Gang injunctions are civil court orders that prohibit alleged gang members from participating in "criminal gang activities and otherwise lawful activities that purportedly constitute a gang nuisance within a defined geographical area." 47 Individuals subjected to gang injunctions may be prevented "from associating with allegedly 'known' gang members in public areas or in public view." 48 These injunctions police access to, and enjoyment of, public space by Black and Latinx youth who are often presumed to be engaged in gang activity. ${ }^{49}$ According to critics, gang injunctions are not only ineffective but unconstitutional, violating civil liberties by labeling youth of color as gang members without evidence, thereby raising clear due process concerns. ${ }^{50}$

story/2020/07/12/report-black-latino-youths-still-getting-arrested-at-higher-rates-in-nyc1300084 [https://perma.cc/8ZQ6-RSRT].

${ }^{44}$ See J.L. Martello, Youth Brawls Draw Police... Disruptive Teens Roll Through Downtown Streets, PITTSBURGH COURIER (Aug. 10, 2016), https://www.newpittsburgh courier.com/2016/08/10/youth-brawls-draw-police-disruptive-teens-roll-through-down town-streets/2/ [https://perma.cc/Q5SH-QBR7] (discussing a "series of Downtown brawls" that erupted following the July 4th fireworks display and an event on August 7, 2016 that led to more than 15 arrests).

45 According to 2018 data, approximately eighty-four percent of youth arrested in Pittsburgh are Black, with Black youth comprising the majority of arrests. Zach Goldstein, Pittsburgh's Trend of Juvenile Arrests Explained in 4 Charts and Maps, 90.5 WESA (June 28, 2018), https://www.wesa.fm/post/pittsburgh-s-trend-juvenile-arrests-explained-4-charts -and-maps\#stream/0 [https://perma.cc/UJE7-A6VH]. Disorderly conduct arrests comprise the fourth most common arrest after aggravated assault, criminal conspiracy, and marijuana possession among Pittsburgh's arrested juvenile population. Id.

46 See, e.g., Melanie Ochoa, LAPD Gang Injunctions Gave Cops a License to Harass and Control Black and Latino Residents, ACLU (Mar, 23, 2018), https://www.aclu.org/blog/ criminal-law-reform/reforming-police/lapd-gang-injunctions-gave-cops-license-harassand-control [https://perma.cc/ZK7S-N9QX].

${ }^{47}$ Order Granting Plaintiffs' Motion to Expand Preliminary Injunction at 2, Youth Justice Coal. v. City of Los Angeles, 264 F. Supp. 3d 1057 (2017) (No. 2:16-cv-07932-VAPRAO), https://www.aclusocal.org/sites/default/files/aclu_socal_yjc_v_la_20180315_order _granting_mtn_expand_pi.pdf [https://perma.cc/N9RJ-3V73].

${ }^{48}$ Id. at 10 (internal citation omitted).

49 James Queally, Los Angeles Barred from Enforcing Nearly All Gang Injunctions, Federal Judge Rules, L.A. TIMES (Mar. 15, 2018), https://www.latimes.com/local/lanow/lame-ln-gang-injunction-court-order-20180315-story.html [https://perma.cc/633Z-YSYH].

${ }^{50}$ Gang Injunctions Fact Sheet, ACLU N. CAL. (May 4, 2010), https://www.aclunc.org/ article/gang-injunctions-fact-sheet [https://perma.cc/8JLC-MFPJ]. 
Efforts to manage Black youth through containment and dispersal strategies ramped up during the so-called war on drugs. ${ }^{51}$ Professor James Forman Jr. describes the harms stemming from those enforcement efforts and the corresponding indignities experienced by Black youth in Washington, D.C. in the 1980s and 1990s in his book, Locking Up Our Own. Forman writes:

[A] culture of impunity flourished with regard to less violent, but more common, police intrusions into the daily lives of black citizens. Swearing and yelling, making belittling remarks, issuing illegitimate orders, conducting random and unwarranted searches, demanding that suspects "get against the wall"- these behaviors rarely led to lawsuits or newspaper coverage. But for residents of the city's poorest neighborhoods, especially young people, this treatment became part of the social contract, a tax paid in exchange for the right to move in public spaces. 52

During the crack epidemic, in cities like Washington, D.C., Chicago, and Los Angeles, fights over public space meant more than access; it implicated concerns raised by members of Black communities regarding neighborhood protection and personal safety. As Forman astutely notes, some commentators at the time viewed the "drug trade's occupation of public space as a form of violence in itself." 53 Professor Forman describes how in response to this "occupation," some Black leaders in Washington, D.C. proposed, and law enforcement adopted, aggressive policing strategies aimed at ridding public spaces of drug dealers and users. ${ }^{54}$ Forman contends that rising crime rates, concerns for public safety, lack of alternatives, and fear led some Black communities to support policies calling for aggressive, "warrior" 55 police tactics and more punitive responses to crime, including stringent punishments for those individuals, overwhelmingly Black, who violated the law. ${ }^{56}$

What history and contemporary trends suggest is that local jurisdictions and communities have used a number of criminal laws and enforcement strategies to police access to use and enjoyment of public space. As the foregoing paragraphs suggest, criminal laws provide discretion to state and private actors to determine who is considered to have a legitimate claim to access and reside in public spaces. Thus, despite the designation of spaces as "public," public spaces are not open and accessible to all, in both a normative and literal sense. Stated differently, the imagined "community" has never included all members

\footnotetext{
51 See Graham Boyd, The Drug War is the New Jim Crow, 35 NACLA REP. ON AMERICAS, 18,18-19 (July/Aug. 2001).

52 JAMES FORMAN, JR., LOCKING UP OUR OWN: CRIME AND PUNISHMENT IN BLACK AMERICA 171 (2017).

$53 \mathrm{Id}$. at 145 .

${ }^{54}$ See id. at $167-70$.

55 Id. at $44,155-56$.

${ }^{56} I d$. at 17-46 (discussing efforts to decriminalize marijuana and the eventual failure of proposed measure); see also id. at 20 (noting that Blacks comprised approximately 80\% of those arrested for marijuana possession).
} 
that reside within a given community. Viewed in this light, the use of criminal law to regulate access to public space becomes a coercive mechanism that can be wielded not only by law enforcement, but also more privileged segments of the community, in order to define the boundaries of their communities - who has access to public space, who will occupy public spaces free of interference, and which behaviors will be tolerated in those public spaces. This possessory interest in public space confers the right to police the boundaries of the particular community, but it is an interest that is not equitably distributed. In gentrifying and gentrified communities, race and class privilege may confer a right to exclude, attaching a bundle of rights and benefits to white communities in particular, and in a manner that approximates Cheryl Harris' formulation of Whiteness as Property. ${ }^{57}$ In this formulation, white communities are entitled to the benefits of order-maintenance policing as part of the primary objective of excluding marginalized "others" from accessing and enjoying public space. ${ }^{58}$

Racism and class privilege are not the only factors at play in the regulation of public space. When individuals are arrested and detained for non-violent and disorderly behaviors linked to disability, criminal law functions to criminalize manifestations of non-normative physical and mental abilities in public spaces. ${ }^{59}$ Aggressive order-maintenance policing disproportionately targets disabled persons who are unsheltered and low-income with no place to go, which is apparent in calls from hospital staff to law enforcement for removal of so-called "unwanted" persons. ${ }^{60}$ For example, in one case, police officers in Portland, Oregon arrested a woman wandering in the waiting area of the Legacy Good Samaritan Hospital. ${ }^{61}$ A police officer arrived at the scene at approximately midnight. ${ }^{62}$ When he arrived, hospital staff informed him that there was an unwanted woman in the waiting area with no medical need and who refused to leave. ${ }^{63}$ Yet, the police report describing the incident notes that the unwanted woman was "76 years old, partially blind, experiencing pain due to 'lingering injuries' sustained during an assault at a homeless shelter, hardly

57 See generally Cheryl I. Harris, Whiteness as Property, 106 HARV. L. REV. 1707 (1993) (investigating how the concepts of race and property are intertwined and reflecting on how property rights are contingent on race, including the right to exclude).

58 See id. at $1745-46,1758$.

${ }^{59}$ See, e.g., Jamelia N. Morgan, Rethinking Disorderly Conduct, 109 CALIF. L. REV. (forthcoming 2021) (manuscript at 33) (on file with the Ohio State Law Journal).

60 See SARAH RADCLIFFE, DisABILITY RigHTS OR., THE "UNWANTEDS": LOOKING FOR HELP, LANDING IN JAIL 3-4, 15 (2019), https://news.streetroots.org/sites/default/files/ Report-The-Unwanteds-Looking-for-Help-Landing-in-Jail-2019-June18.pdf [https://per ma.cc/7VT7-T8Y6] [hereinafter THE "UNWANTEDS"]; see also Criminalization of Individuals with Severe Psychiatric Disorders, MENTAL HEALTH POL'Y ORG., https://mental illnesspolicy.org/consequences/criminalization.html [https://perma.cc/U7Q4-D3U3] (discussing such cases as so-called "mercy bookings").

61 THE "UNWANTEDS", supra note 60, at 4.

${ }^{62} \mathrm{Id}$.

${ }^{63} \mathrm{Id}$. 
able to walk, and 'most likely suffering from the onset of Dementia."'64 Earlier that day, the woman had been seen at the emergency department of another area department. ${ }^{65}$ After attempts to call Adult Protective Services and engage mental health professionals failed, police arrested the seventy-six-year-old woman and then booked her into the Multnomah County jail. ${ }^{66}$

As if historical and ongoing exclusion and marginalization on the basis of race, class, gender identity, disability, is not enough, the current pandemic makes it even more apparent that there is a need for structural change. Legal reform provides one opportunity for change, though for reasons discussed below, there is reason to be skeptical of transformative change through law. Existing constitutional protections do little to prevent marginalized groups from criminalization in public spaces. This failure to protect the most marginalized people reveals not only the law's role in upholding these vulnerabilities, but also the subordinating role of criminal law in sustaining, through under-protection, conditions of precarity.

\section{Constitutional Protections Against Policing Marginality: A FoCUS ON STATUS OFFENSES}

Regulating marginalized groups in public space can be traced to efforts by states and localities to promote order and promote the general welfare. ${ }^{67}$ Yet, as I've suggested, regulating public space often targets for criminalization members of historically marginalized groups. What constitutional protections exist to limit such criminal regulation? Of course, state police power is at its height in efforts to maintain order-however vaguely defined-and preserve access to and enjoyment of public space. As the Supreme Court has stated:

When clear and present danger of riot, disorder, interference with traffic upon the public streets, or other immediate threat to public safety, peace, or order, appears, the power of the State to prevent or punish is obvious .... . This Court respects, as it must, the interest of the community in maintaining peace and order on its streets. 68

Perhaps this is why few legal scholars have questioned the legitimacy of using criminal law as a tool for regulating and managing access to public space, which is in large part a set of policing activities centered on enforcing social

\footnotetext{
${ }^{64} \mathrm{Id}$.

$65 \mathrm{Id}$.

$66 \mathrm{Id}$.

${ }^{67}$ See Benno Weisberg, Comment, When Punishing Innocent Conduct Violated the Eighth Amendment: Applying the Robinson Doctrine to Homelessness and Other Contextual “Crimes,” 96 J. CRIM. L. \& CRIMINOLOGY 329, 356 (2005).

${ }^{68}$ Feiner v. New York, 340 U.S. 315, 320 (1951) (quoting Cantwell v. Connecticut, 310 U.S. 296, 308 (1940)).
} 
order and preventing damage to property or infringing upon property interests. ${ }^{69}$ Historical and ongoing conflicts over access to, use, and enjoyment of public space highlight the central problems of criminalizing crimes committed in public because the accused had nowhere else to go. The use of criminal law to regulate access to, and use of, public space is never exclusively about criminal acts committed in public per se. Broad and extensive criminal laws necessitate enforcement priorities, which means that certain groups will be targeted for policing more than others-historically those "others" who do not fit white, middle class, cisgender, heterosexual norms. ${ }^{70}$ Furthermore, criminalizing behaviors that would not be criminal if done in private spaces often risks criminalizing acts of necessity. ${ }^{71}$ The Supreme Court's decision in Powell v. Texas acknowledged some of these problems but failed to resolve them. ${ }^{72}$

Powell involved a constitutional challenge by a "chronic alcoholic" who had challenged his conviction for public intoxication. ${ }^{73}$ The Supreme Court upheld the conviction in a plurality opinion. ${ }^{74}$ Four Justices held that Powell could not demonstrate that alcoholism was a status or condition within the definition contemplated under Robinson v. California. ${ }^{75}$ The court determined even if alcoholism could be defined as a disease or condition, it was not clear that Powell had been unable to control his impulse to drink and lacked the ability to control himself so much so that he could not resist the impulse to go in public while intoxicated..$^{76}$ Justice Marshall, writing for the plurality, emphasized that it was the public nature of Powell's voluntary conduct that made him susceptible to criminal sanction. Powell was convicted, according to the plurality, not for the status of being a chronic alcoholic but for "being in public while drunk on a particular occasion." 77 In supporting its reasoning, the Court made sure to note that the State of Texas had not sought to "regulate [Powell's] behavior in the

${ }^{69}$ See Debra Livingston, Police Discretion and the Quality of Life in Public Places: Courts, Communities, and the New Policing, 97 ColuM. L. REV. 551, 581-91 (1997); see also Dan M. Kahan, Social Influence, Social Meaning, and Deterrence, 83 VA. L. REV. 349, 370-71 (1997). But see Bernard E. Harcourt, Reflecting on the Subject: A Critique of the Social Influence Conception of Deterrence, the Broken Windows Theory, and OrderMaintenance Policing New York Style, 97 MicH. L. REV. 291, 293, 295 (1998).

${ }^{70}$ See Radley Balko, There's Overwhelming Evidence that the Criminal Justice System Is Racist. Here's the Proof., WASH. POST (June 10, 2020), https://www.washingtonpost.com /graphics/2020/opinions/systemic-racism-police-evidence-criminal-justice-system/ [https://perma.cc/X8F4-WP2C]; Ryan, supra note 34.

${ }^{71}$ See Weisberg, supra note 67, at 356 ("[C]ourts . . . ought to recognize the policies behind laws targeting innocent conduct. The two primary policy rationales for camping ordinances - which punish sleeping, eating and other victimless activities when performed in public - are fairly intuitive, although one is considered by many to be legitimate, while the other remains unspoken.").

72 Id. at $337-41$.

73 Powell v. Texas, 392 U.S. 514, 517-18 (1968).

74 See id. at 537 (plurality opinion).

${ }^{75} \mathrm{Id}$. at $532-34$.

${ }^{76}$ Id. at 535 .

${ }^{77}$ Id. at 532 . 
privacy of his own home," but instead "imposed upon [Powell] a criminal sanction for public behavior which may create substantial health and safety hazards, both for [Powell] and for members of the general public, and which offends the moral and esthetic sensibilities of a large segment of the community." 78 Ultimately, a plurality of justices declined to overturn Powell's conviction, concluding that the evidence in the record failed to establish that chronic alcoholics in general-and Powell in particular - were both compelled to drink and compelled to get drunk in public. ${ }^{79}$

Justice White was the fifth vote in the Powell decision. ${ }^{80}$ In concurrence Justice White noted that yielding to a compulsion cannot constitutionally be a crime, but, in this case, Powell could have been drunk in private. ${ }^{81}$ Justice White, in concurrence, voted to affirm Powell's conviction, agreeing with the plurality that the evidence in the record did not support Powell's claim that his alcoholism compelled his conduct to manifest in public. At the same time, his opinion carefully distinguished chronic alcoholics who were compelled to public intoxication because of their "disease" and chronic alcoholics who were drunk in public not only because of addiction, but also because they had no place to go to drink but in public places. ${ }^{82}$ As Justice White explained:

The fact remains that some chronic alcoholics must drink and hence must drink somewhere. Although many chronics have homes, many others do not. For all practical purposes the public streets may become home for these unfortunates, not because their disease compels them to be there, but because, drunk or sober, they have no place else to go and no place else to be when they are drinking. This is more a function of economic station than of disease, although the disease may lead to destitution and perpetuate that condition. For some of these alcoholics I would think a showing could be made that resisting drunkenness is impossible and that avoiding public places when intoxicated is also impossible. As applied to them this statute is in effect a law which bans a single act for which they may not be convicted under the Eighth Amendment - the act of getting drunk. ${ }^{83}$

The Supreme Court has yet to resolve the conundrum Justice White discusses in his concurrence. However, more recently, the Ninth Circuit's decision in Boise v. Martin attempted to resolve the conflict by focusing in on choice as a prerequisite to criminalizing conduct by actors compelled to engage in life-sustaining conduct in public space. ${ }^{84}$ In Boise, six plaintiffs, some homeless and some who used to be homeless, challenged the constitutionality

78 Id.

${ }^{79}$ Powell, 392 U.S. at 535, 537.

${ }^{80} \mathrm{Id}$. at $548-54$ (White, J., concurring).

${ }^{81} \mathrm{Id}$. at $548,553$.

82 Id. at 551, 553.

${ }^{83} \mathrm{Id}$. at 551 (footnote omitted).

${ }^{84}$ Martin v. City of Boise, 920 F.3d 584, 617 (9th Cir. 2019), modifying, 902 F.3d 1031 (9th Cir. 2018), cert denied, 140 S. Ct. 674 (2019). 
of Boise's Camping Ordinance and Disorderly Conduct Ordinance. ${ }^{85}$ The six plaintiffs were cited for camping on public property in Boise, Idaho. ${ }^{86}$ The Ninth Circuit held that "an ordinance violates the Eighth Amendment insofar as it imposes criminal sanctions against homeless individuals for sleeping outdoors, on public property, when no alternative shelter is available to them." 87

The ruling prompted a vociferous dissent written by Judge Milan Smith that included, in a rather unusual move, an unattributed photo of a sidewalk in Los Angeles County lined with tents. ${ }^{88}$ The Supreme Court denied the City of Boise's certiorari petition seeking review of the Ninth Circuit's decision, prompting a flurry of editorials and commentaries, some calling the decision a "blow to cities," 89 and effectively, "deny[ing] cities the right to combat homeless encampments." $" 90$ In a written statement, former Boise Mayor Dave Bieter conveyed similar alarm:

"We believe that the 9th Circuit's most recent decision in this case leaves the city's fundamental ability to protect public health and safety on its own streets very uncertain"...."Without further clarification by the courts, our most vulnerable residents - the very people this suit purports to be protectingwould be victimized by the conditions in camps that could crop up." 91

Despite the outcry by some commentators that the Boise decision limits the ability of cities to promote public safety and public health, claims that municipalities now lack the ability to clear encampments or other obstructions in public spaces (perhaps through enacting restrictions limiting the times and

${ }^{85} \mathrm{Id}$. at $603-04$.

86 Id. at 606.

${ }^{87} \mathrm{Id}$. at 604 .

${ }^{88}$ Id. at 597 (Smith, J., with Callahan, Bea, Ikuta, Bennett, \& R. Nelson, JJ., dissenting).

${ }^{89}$ See Erika D. Smith, Supreme Court Decision on Homeless Case Is a Blow to Cities Wanting More Policing Powers, L.A. TIMES (Dec. 16, 2019), https://www.latimes.com/ california/story/2019-12-16/homeless-boise-ruling-case-supreme-court [https://perma.cc/ 2B9K-TW7K].

${ }^{90}$ Stephen Eide, Opinion: The Supreme Court Just Denied Cities the Right to Combat Homeless Encampments, L.A. TIMES (Dec. 16, 2019), https://www.latimes.com/opinion/ story/2019-12-16/supreme-court-denied-cities-right-to-combat-homeless-camps [https://per ma.cc/2AE4-UH8B]. But see Martin, 920 F.3d at 589-90 (Berzon, J., concurring) ("The [homeless] crisis continued to burgeon while ordinances forbidding sleeping in public were on the books and sometimes enforced. There is no reason to believe that it has grown, and is likely to grow larger, because Martin held it unconstitutional to criminalize simply sleeping somewhere in public if one has nowhere else to do so.").

${ }^{91}$ Xavier Ward, U.S. Supreme Court Decides Not to Hear Boise Case on Homelessness, BOISE WKLY. (Dec. 16, 2019), https://www.idahopress.com/boiseweekly/news/citydesk/us-supreme-court-decides-not-to-hear-boise-case/article_23c49815-2db1-5152-aaa3-a33ba4 adeda6.html [https://perma.cc/D4HY-UGSK]. 
places where public camping may legally occur) are largely overblown. ${ }^{92}$ As Judge Berzon notes in concurrence:

The opinion clearly states that it is not outlawing ordinances 'barring the obstruction of public rights of way or the erection of certain structures,' such as tents ... and that the holding 'in no way dictate[s] to the City that it must provide sufficient shelter for the homeless, or allow anyone who wishes to sit, lie, or sleep on the streets . . at any time and at any place. ${ }^{93}$

In short, what Boise does (it seems) is eliminate criminalization as a tool for regulating access at all times to public space-sleeping, camping, etc.-where there is not the choice of available and accessible housing.

Even so, the decision may not be enough to prevent criminalization of lifesustaining conduct by unhoused persons in public spaces. In centering the discussion on choice, the Boise court fails to grapple with the actual social and cultural conditions under which choice is exercised by persons vulnerable to criminal sanction in public spaces. For example, does the quality of the homeless shelter factor into determinations of what is "practically available" 94 to houseless individuals? In Boise, the Ninth Circuit noted in a footnote that "our holding does not cover individuals who do have access to adequate temporary shelter, whether because they have the means to pay for it or because it is realistically available to them for free, but who choose not to use it." 95 Is the shelter practically unavailable if the unhoused individual believes that, as a survivor of intimate partner violence, that person will not be safe residing at a

\footnotetext{
92 See Martin, 920 F.3d at 617 n.8 ("Nor do we suggest that a jurisdiction with insufficient shelter can never criminalize the act of sleeping outside. Even where shelter is unavailable, an ordinance prohibiting sitting, lying, or sleeping outside at particular times or in particular locations might well be constitutionally permissible. So, too, might an ordinance barring the obstruction of public rights of way or the erection of certain structures. Whether some other ordinance is consistent with the Eighth Amendment will depend, as here, on whether it punishes a person for lacking the means to live out the 'universal and unavoidable consequences of being human' in the way the ordinance prescribes.") (citations omitted); Theodore B. Olson \& TheANe Evangelis, Gibson Dunn, Martin V. City of Boise Will ENSURE THE SPREAD OF ENCAMPMENTS THAT THREATEN Public HEALTH AND SAFETy 3-7 (Aug. 2019), https://www.gibsondunn.com/wp-content/uploads/2019/08/Martin-v.-BoiseWhite-Paper.pdf [https://perma.cc/B4AK-4C5E] [hereinafter GIBSON DUNN] (discussing how, as a result of the Martin ruling, cities will be prevented from stopping the spread of encampments and, in effect, threatening public health and safety); $i d$. at 2 (noting that Martin held that governments may not enforce ordinances that criminalize public camping unless there is shelter available for everyone).

93 Martin, 920 F.3d at 589 (Berzon, J., concurring) (citations omitted) (quoting Martin v. City of Boise, 902 F.3d 1031, 1048 (9th Cir. 2018)).

${ }_{94}$ Id. at 618 ("We conclude that a municipality cannot criminalize such behavior consistently with the Eighth Amendment when no sleeping space is practically available in any shelter.").

${ }^{95} \mathrm{Id}$. at 617 n. 8 .
} 
shelter with a history or high rate of sexual assault and violence? ${ }^{96}$ The court similarly does not examine the ways in which enforcement priorities drive which conduct and which locations may be targeted for enforcement and how that may affect available choices. Would an individual be regarded as lacking choice, therefore preventing the state from targeting that person for punitive sanction, if the individual refused placement in a shelter hundreds of miles away from the place where the person has called home, in an effort to remove that individual and others from an affluent city, gentrified, or rapidly gentrifying area? ${ }^{97}$ The framework of choice on its own will not resolve these tensions.

But the shortcomings of the choice framework in protecting against criminalization of status or condition, as ongoing debates about whether the Eighth Amendment prohibits criminalizing involuntary acts suggests, ${ }^{98}$ are not the only reason to suspect constitutional protections against status-based criminalization will be limited. The choice approach obscures a central function of criminal law: its public ordering function. ${ }^{99}$ Failure to recognize this central function of criminal law may lead to overstatements of the reach of constitutional protections against acts that are "involuntary and inseparable from status," as welcomed as those protections may be for opponents of criminalization. 100

\section{CRiminal LaW's Public ORdering FunCtion \& THE POLICING of Marginality in Public SPACE}

In a discussion of public ordering function of criminal law, Alice Ristroph notes that "[q]uite often, the interventions of criminal law are designed

\footnotetext{
${ }^{96} C f$. Margot B. Kushel, Jennifer L. Evans, Sharon Perry, Marjorie J. Robertson, \& Andrew R. Moss, No Door to Lock: Victimization Among Homeless and Marginally Housed Persons, 163 ARChIVE InTERnAl MeD. 2492, 2495 (2003) (“One third of women (32.3\%), $27.1 \%$ of men, and $38.1 \%$ of transgendered persons reported either sexual or physical victimization in the previous year.").

97 See Mike Baker, Homeless Residents Got One-Way Tickets Out of Town. Many Returned to the Streets., N.Y. TIMES (Sept. 14, 2019), https://www.nytimes.com/2019/ 09/14/us/homeless-busing-seattle-san-francisco.html [https://perma.cc/9XWQ-J5QV]; Rick Paulas, Instead of Helping Homeless People, Cities are Bussing Them Out of Town, VICE (Feb. 13, 2020), https://www.vice.com/en_us/article/bvg7ba/instead-of-helping-homelesspeople-cities-are-bussing-them-out-of-town [https://perma.cc/2Y7L-GBT6].

98 See, e.g., David Rudin, "You Can't Be Here”: The Homeless and the Right to Remain in Public Space, 42 N.Y.U. ReV. L. \& Soc. Change 309, 312-16 (2018); Hannah Kieschnick, Note, A Cruel and Unusual Way to Regulate the Homeless: Extending the Status Crimes Doctrine to Anti-Homeless Ordinances, 70 STAN. L. REV. 1569, 1591-94 (2018); Elizabeth M. M. O'Connor, Note, The Cruel and Unusual Criminalization of Homelessness: Factoring Individual Accountability into the Proportionality Principle, 12 TEX. J. ON CIV. LIBERTIES \& CIV. RTS. 233, 246-58 (2007).

${ }^{99}$ See Ristroph, supra note 11 , at 78 .

${ }^{100}$ Martin v. City of Boise, 920 F.3d 584, 617 (9th Cir. 2019), modifying, 902 F.3d 1031 (9th Cir. 2018), cert denied, 140 S. Ct. 674 (2019).
} 
to ... classify people and arrange them in a specific manner."101 As Ristroph maintains, "order" in this sense operates in practice more like a verb, as in the "outcome of a continual and dynamic process of ordering," rather than a clearly defined, objective, "fixed status." 102 Criminal law's public ordering function can reinforce social or status hierarchies including those based on race, gender identity, and disability. ${ }^{103}$ Indeed, such public ordering functions may be justified by deeply entrenched stereotypes and norms linking certain negatively racialized and historically marginalized groups to criminality and disorder. ${ }^{104}$

But beyond this, this process of public ordering features prominently in uses of criminal law to manage public space. In managing access to public space, criminal law can be conceived as functioning to sort and classify people while in those public spaces based on their perceived risk to (physical and social) order. As noted, the experience of order maintenance policing among houseless individuals provides a case in point. Houseless individuals are labeled as risks in public - risks to safety, risks to public access, risks to property values - to be closely monitored and regulated within those public spaces. ${ }^{105}$ Because criminal law is a readily available tool for social control, social problems like the lack of affordable housing are routinely characterized as problems criminal law can effectively address, even without any empirical support. ${ }^{106}$ Criminalization becomes the response to the problem not just because in an era marked by mass criminalization it is easy to cast criminal laws as an acceptable response to social problems, but also because the public ordering function comprises a large part of what (though often unstated) criminal law is used for: regulating such marginalized people in public spaces. In this light, it is easier to view the criminal regulation of homelessness as part of a long history of criminalizing marginality and precarity in public space and part of a broader ecosystem of criminal law enforcement aimed broadly at regulating social and physical disorder. This broad ecosystem includes law enforcement, but also includes aggressive policing efforts by private citizens, actively encouraged and empowered to monitor and look out for suspicious persons through an array of phone-in reporting systems and apps. ${ }^{107}$

101 Ristroph, supra note 11 , at 79.

102 Id. at 64, 76 .

103 Morgan, supra note 59 (manuscript at 6).

${ }^{104}$ See, e.g., Andrew Johnson, Foucault: Critical Theory of the Police in a Neoliberal Age 141 THEORIA J. Soc. \& POL. THEORY 5,21-22 (2014) ("The militarisation of the police is juxtaposed with the systematic racism evident in the mass policing and incarceration of minority populations.... The over-imprisoning and over-policing... is an intentional economic ordering of society ....”) (citations omitted).

105 See, e.g., GIBSON DUNN, supra note 92, at 4-10.

106 See James Cullen, The History of Mass Incarceration, BRENNAN CTR. FOR JUST. (July 20, 2018), https://www.brennancenter.org/our-work/analysis-opinion/history-mass-incarce ration [https://perma.cc/3SGN-468K].

107 See Hanna Kozlowska, Are Neighborhood Watch Apps Making Us Safer?, QUARTZ (Oct. 29, 2019), https://qz.com/1719954/mobile-phone-apps-like-citizen-aim-to-curbneighborhood-crime/ [https://perma.cc/S5Q5-UU3T]. 
So what are the implications for criminal law's public ordering function and the policing of marginality in public space? I'll offer just a few important implications. For one, history suggests that policing people "out of place"- the "disorderly," the "vagrants" - in public space is surely not new, but rather the recent iteration of the ways in which society regulates marginality in public space. ${ }^{108}$ Contemporary laws that criminalize public space both reflect and reinforce social and status hierarchies, as well as demonstrate how criminal law enforcement mediates access to public space. Moreover, criminal law enforcement reinforces specific social meanings that in turn reinforce social status hierarchies that vary across time and place. These social meanings may work to associate "vagrants" with people who fail to conform to racial and gender norms, or distinguish "disorderly" persons from "orderly" persons based on class-based or ableist stereotypes. ${ }^{109}$ What these specific meanings or stereotypes are should serve the basis for future research. For instance, what social meanings do the enforcement of trespass or other quality-of-life offenses reinforce? How does the disproportionate policing of quality-of-life offenses within Black and Brown communities reinforce ideologies, policies, and practices that justify their segregation in low-income, underserved, and underresourced communities? Recent attention to the subordinating role of criminal law enforcement is an important direction for critical criminal legal scholarship to take. ${ }^{110}$ Finally, what does the historical and ongoing role of subordination through criminal law suggest about whether criminal law enforcement is ever truly on behalf of the people, or the "community"? Recent critiques of efforts to disrupt the twin social harms of mass criminalization and mass incarceration by democratizing criminal justice suggest the problems with efforts that seek to align reform efforts with uniform notions of community interest or input. 111

As I have argued, if we center public space in our analysis of criminal law's public ordering - and subordinating function - we can better see how access to space informs notions of actual and normative community. We can see how policing marginality in public space is as much about community, and conceptions of community, as it is about democratic citizenship. ${ }^{112}$ In making

108 See, e.g., Aron, supra note 24.

109 See, e.g., Roberts, supra note 41, at 788, 804.

110 See, e.g., Monica C. Bell, Anti-Segregation Policing, 95 N.Y.U. L. REV. 650, 656 (2020); Priscilla A. Ocen, Birthing Injustice: Pregnancy as a Status Offense, 85 GEO. WASH. L. REV. 1163, 1198 (2017); Jocelyn Simonson, Police Reform Through a Power Lens, 130 YALE L.J. (forthcoming 2021) (manuscript at 5,7) (on file with the Ohio State Law Journal).

111 See, e.g., John Rappaport, Some Doubts About “Democratizing” Criminal Justice, 87 U. CHI. L. REV. 711, 713, 729 (2020); Dorothy E. Roberts, Democratizing Criminal Law as an Abolitionist Project, 111 Nw. U. L. Rev. 1597, 1599, 1604 (2017); see also Ngozi Okidegbe, Democratizing Potential of Algorithms?, 53 CONN. L. REV. (forthcoming 2021) (manuscript at 33) (on file with the Ohio State Law Journal); Jocelyn Simonson, Essay, The Place of "The People" in Criminal Procedure, 119 ColuM. L. REV. 249, 249, 279 (2019).

${ }^{112}$ See Susan Schweik, Kicked to the Curb: Ugly Law Then and Now, 46 HARV. CIV. RTS-CiV. Liberties L. ReV. AmiCUS, at *1, *16 (2011), https://harvardcrcl.org/wp-cont ent/uploads/sites/10/2013/01/Schweik_Vol46_Amicus.pdf [https://perma.cc/Q5AC-5LE5] 
this point, I rely in part on Judith Butler's theory of performativity and the connections among the body, public space, and democracy. As Butler writes:

"The people" are not a given population, but are rather constituted by the lines of demarcation that we implicitly or explicitly establish.... Not every discursive effort to establish who "the people" are works. The assertion is often a wager, a bid for hegemony. So when a group or assembly or orchestrated collectivity calls itself "the people," they wield discourse in a certain way, making presumptions about who is included and who is not, and so unwittingly refer to a population who is not .... [W] hen the struggle over deciding who belongs to "the people" gets intense, one group opposes its own version of "the people" to . . . the proposed version of "the people."113

Butler contends that the concept of "the people" cannot exist without some form of exclusion: ${ }^{114}$

Of course, it is true that any version of "the people" that excludes some of the people is not inclusive and, therefore, not representative. But it is also true that every determination of "the people" involves an act of demarcation that draws a line ... . [T] here is no possibility of "the people" without a discursive border drawn somewhere, either traced along the lines of existing nation-states, racial or linguistic communities, or political affiliation. The discursive move to establish "the people" in one way or another is a bid to have a certain border recognized, whether we understand that as a border of a nation or as the frontier of that class of people to be considered "recognizable" as a people. ${ }^{115}$

In this moment, where the possibilities for transformative change provide those concerned with eliminating the subordinating effects of criminal law and the criminal legal system with a reason for optimism, we should not miss out on the opportunity to explore how the present moment reveals both the precarity of certain bodies in public space, as well as the precarity of democratic and inclusive citizenship as a political and social ideal.

("Margaret Kohn has delineated three kinds of common arguments for street peoples' right to the city: the liberal (assertion of individual freedom and rights), the romantic (celebration of countercultural modes of living), and - what is for her the most effective approach - the democratic."); see also id. ("Through their presence, people who are homeless are also in a better position to demand what they need.' Art Honeyman's approach to the politics of city space, resolutely democratic in this sense, insists on the necessity and the vitality of regularly 'seeing others,' a model directly borne from a disability sensibility, the long experience of being told to hide from public view. His poems make clear that it matters not only that we see others but where we see other: persons, or disability, relegated only to the verge or the gutter or the curb are in no position to articulate demands.") (footnotes omitted) (quoting Anastasia Loukaitou-Sideris \& Renia Ehrenfeucht, Sidewalks: Conflict And Negotiation over Public Space 187A (2009)).

113 Judith Butler, Notes Toward a Performative Theory of Assembly 3-4 (2015).

114 Id. at 5.

115 Id. 
